\title{
Association of Patient-Provider Teach-Back Communication with Diabetic Outcomes: A Cohort Study
}

\author{
Young-Rock Hong, PhD, MPH, Jinhai Huo, PhD, MD, MSPH, Ara Jo, PhD, MS, \\ Michelle Cardel, PhD, MS, RD, and Arch G. Mainous III, PhD
}

Background and Objectives: The purpose of this study is to examine the patterns of patient teach-back experience (also known as "interactive communication loop") and determine its association with risk for diabetic complications and hospitalization, and health expenditures among individuals with diabetes.

Methods: A retrospective cohort study of 2901 US adults aged 18 years or older with a confirmed diagnosis of diabetes was conducted using data from the 2011 to 2016 Longitudinal Medical Expenditure Panel Survey. Survey-design adjusted multivariable models were used to examine whether having patient teach-back experience at the baseline year (Year 1) is associated with development of diabetic complications, hospitalization, and health expenditure at follow-up year (Year 2). Health expenditures were adjusted for inflation and expressed in 2017 US dollars. All adjusted models included patient sociodemographic and clinical characteristics.

Results: Analyses found that patients with teach-back experience were less likely to develop diabetic complications (adjusted odds ratio [AOR], 0.70; 95\% CI, 0.52-0.96) and be admitted to the hospital due to diabetic complications (AOR, 0.51; 95\% CI, 0.29-0.88) at 1-year followup. Patients having teach-back experience also had a significantly smaller increase in total expenditures of $\$ 1920$ compared with those not having teach-back of $\$ 3639$ (a differential change of $-\$ 1579 ; 95 \% \mathbf{C I},-\$ 1717$ to $-\$ 1443 ; P<.001)$.

Conclusions: Teach-back could be an effective communication strategy that has potential to improve health outcomes, resulting in savings in diabetes care. ( $\mathrm{J}$ Am Board Fam Med 2020;33:903-912.)

Keywords: Diabetes Complications, Diabetes Mellitus, Health Expenditures, Health Communication, Health Literacy, Hospitalization, Longitudinal Studies, Outcomes Assessment, Patient-Centered Care, Primary Health Care, Retrospective Studies, Surveys and Questionnaires

\section{Introduction}

Diabetes mellitus is a growing public health concern in the world. The International Diabetes Federation has estimated 425 million people live with diabetes around the globe; nearly $\$ 727$ billion

This article was externally peer reviewed.

Submitted 12 May 2020; revised 15 July 2020; accepted 20 July 2020.

From the Department of Health Services Research, Management and Policy, University of Florida, Gainesville (YRH, JH, AJ, AGM); Department of Health Outcomes and Biomedical Informatics, University of Florida, Gainesville (MC); Department of Community Health and Family Medicine, University of Florida, Gainesville (AGM).

Funding: None.

Conflict of interest: None.

Author contributions: YRH and AGM contributed to the study design, methods, and discussion; performed the statistical analyses; interpreted the data; and drafted and revised
USD were spent to provide care for diabetes treatment in 2017. In the United States, 1 in 3 individuals are projected to have diabetes by $2050 .^{2}$ Those with diabetes are at increased risk of medical complications including premature death and lifelong severe impairments and disabilities. ${ }^{3-6}$ Given the significant burden on health care, there is an increasing need for effective and efficient means of providing care that could attenuate this trend.

the manuscript. JH, AJ, and MC contributed to the study design, methods, and discussion; interpreted the data; and reviewed and edited the manuscript.

Corresponding author: Young-Rock Hong, PhD, MPH, Department of Health Services Research, Management and Policy in the College of Public Health and Health Professions, University of Florida-Gainesville, PO Box 100195, University of Florida, Gainesville, FL 32610 (E-mail: youngrock.h@phhp.ufl.edu). 
Diabetes is a complex condition requiring active patient self-management and continuous care from health care providers. ${ }^{7-9}$ The goal of diabetes care management is to prevent or delay the development of diabetes-associated complications, decrease mortality, and maintain or improve the overall quality of life among those living with the disease. ${ }^{10}$ To achieve this goal, diabetes care management encompasses both medical treatments by clinicians and self management by patients. ${ }^{8,10,11}$ Therefore, patient education that improves patient knowledge and compliance to treatment comes first as a critical component of primary diabetes care. ${ }^{8}$

Teach-back is a communication technique to assess patient understanding by checking health information delivered in communication between patient and provider. ${ }^{12}$ A simple asking-back question in the teach-back method can create the process of "interactive communication loop" enabling providers to ensure that essential health information is delivered correctly and well understood by patients or their caregivers. ${ }^{12-14}$ If they demonstrate poor recall or lack of understanding, providers then repeat, clarify, or tailor the information to a format that is commonly understood (this step is known as "closing the loop"). ${ }^{12-14}$ Better communication and interactions between patients and providers promote effective coping strategies and self management required for those with diabetes. ${ }^{12,15-23}$ In this regard, the teach-back method could be promising to improve the relationship and close the loop in diabetic patient care.

Previous work has suggested that improved patient-provider relationships throughout the teach-back strategy could explain better patient health outcomes. ${ }^{18,23,24}$ For example, higher patient satisfaction and trust-building by effective interaction with health care providers would help ensure continuity of care, ${ }^{19-22}$ resulting in improved disease management and health outcomes (eg, less hospitalization). ${ }^{15-18}$ However, there is no known study to demonstrate and confirm this association in the diabetes care spectrum. Furthermore, most of the studies that documented the use of teachback are based on pilot interventions and data having limited generalizability. ${ }^{25-27}$ To address these gaps, this study sought to examine the association of teach-back with patient-reported health outcomes among individuals with diabetes. We hypothesized that diabetic patients who had teach-back experience are less likely to develop diabetes-related complications, and this would result in a reduction in hospitalization risk and health expenditures.

\section{Research Design and Methods \\ Data Source}

This was a retrospective, observational cohort study to evaluate the effect of having teach-back experience on health outcomes among patients with diabetes. We used data from the 2011 to 2016 Longitudinal Medical Expenditure Panel Survey (MEPS). The MEPS is administered annually by the US Agency for Health care Research and Quality and applies an overlapping panel design including 5 rounds of interviews over a span of 2 full calendar years. ${ }^{28,29}$ Specifically, each year, 2 panels are selected for the survey comprised of 1 panel in its first year (Year 1) and the other panel in its second year (Year 2) of data collection. ${ }^{28}$ In this study, we considered Year 1 survey data as the baseline period and Year 2 as the follow-up period for each panel. We used 6-year pooled MEPS longitudinal panel data (panels 16 to 20) to secure an adequate sample size and linked to Medical Conditions and Hospital Inpatient Stays Files to validate and supplement the clinical and medical events information provided by respondents in the MEPS. The University of Florida institutional review board approved this study and waived the need for informed consent because all data were retrospective and deidentified.

\section{Study Population}

The study sample included US adults aged 18 years or older with a confirmed diagnosis of diabetes (both type I and type II) without complications given that diabetic complications could interfere with treatment adherence and accurate outcome assessment. ${ }^{30}$ The study participants were identified using the Clinical Classification Code (CCC) 049. The CCC codes are based on the International Classification of Diseases, Ninth Revision, Clinical Modification (ICD-9-CM) containing more than 14,000 diagnosis codes. ${ }^{31}$ A full list of aggregated ICD-9-CM conditions and the CCC codes is presented in Appendix Table 1. We included those who had 1 or more visits to their usual source of providers (identified as family medicine, internal medicine, and general practice) and excluded those who had no visit to care since they had no interaction with health care providers. Further, patients 
Table 1. Baseline Characteristics of Study Population by Teach-Back Experience

\begin{tabular}{|c|c|c|c|c|c|}
\hline & \multicolumn{2}{|c|}{ Teach-Back } & \multicolumn{2}{|c|}{ Non-Teach-Back } & \multirow[b]{2}{*}{$P$-Value } \\
\hline & No. & $\%(95 \% \mathrm{CI})^{*}$ & No. & $\%(95 \% \mathrm{CI})^{*}$ & \\
\hline \multicolumn{6}{|l|}{ Age group, years } \\
\hline 18 to 49 & 186 & $21.8(18.2$ to 25.3$)$ & 442 & 19.5 (17.3 to 21.6$)$ & .602 \\
\hline 50 to 59 & 217 & $26.4(22.4$ to 30.3$)$ & 564 & 24.3 (21.8 to 26.9$)$ & \\
\hline 60 to 64 & 121 & $15.4(12.2$ to 18.6$)$ & 323 & $16.0(13.8$ to 18.1$)$ & \\
\hline 65 to 69 & 110 & $12.8(10.1$ to 15.4$)$ & 269 & 14.0 (11.8 to 16.2$)$ & \\
\hline $70+$ & 171 & $23.7(19.1$ to 28.3$)$ & 498 & $26.2(23.4$ to 29.0$)$ & \\
\hline Median age (IQR) & & $59(51$ to 68$)$ & & $61(51$ to 59$)$ & .354 \\
\hline Sex & & & & & .977 \\
\hline Female & 447 & $52.5(48.6$ to 56.5$)$ & 1151 & $52.6(49.9$ to 55.4$)$ & \\
\hline Male & 358 & 47.5 (43.5 to 51.4$)$ & 945 & $47.4(44.6$ to 50.1$)$ & \\
\hline Race/ethnicity & & & & & $<.001$ \\
\hline Non-Hispanic White & 230 & 49.5 (44.6 to 54.4$)$ & 821 & $62.8(59.5$ to 66.1$)$ & \\
\hline Non-Hispanic Black & 243 & $19.9(16.9$ to 23.0$)$ & 522 & $14.9(12.6$ to 17.1$)$ & \\
\hline Hispanic & 245 & $19.0(15.5$ to 22.4$)$ & 551 & $14.2(12.0$ to 16.4$)$ & \\
\hline Other† & 87 & $11.6(8.2$ to 15.0$)$ & 202 & $8.1(6.3$ to 10.0$)$ & \\
\hline Education & & & & & .156 \\
\hline Less than high school & 377 & $40.5(36.5$ to 44.5$)$ & 895 & $36.0(33.3$ to 38.8$)$ & \\
\hline High school/GED & 188 & $25.2(20.9$ to 29.4$)$ & 518 & $25.6(22.9$ to 28.3$)$ & \\
\hline Some college & 144 & 19.4 (15.9 to 22.8$)$ & 421 & $23.8(21.3$ to 26.4$)$ & \\
\hline Bachelor's or beyond & 96 & $15.0(11.7$ to 18.2$)$ & 262 & $14.5(12.3$ to 16.7$)$ & \\
\hline Family incomeł & & & & & .803 \\
\hline Poor & 236 & $21.6(17.8$ to 25.4$)$ & 588 & $20.0(17.6$ to 22.5$)$ & \\
\hline Low income & 149 & $16.4(13.2$ to 19.7$)$ & 381 & $15.5(13.2$ to 17.7$)$ & \\
\hline Middle income & 228 & $29.2(24.4$ to 34.1$)$ & 608 & $31.2(28.3$ to 34.1$)$ & \\
\hline High income & 192 & $32.7(27.7$ to 37.8$)$ & 519 & 33.3 (29.9 to 36.6$)$ & \\
\hline Marital status & & & & & .569 \\
\hline Not married & 381 & 41.8 (37 to 46.6$)$ & 992 & $43.5(40.5$ to 46.5$)$ & \\
\hline Married & 424 & $58.2(53.4$ to 63$)$ & 1104 & $56.5(53.5$ to 59.5$)$ & \\
\hline Employment & & & & & .721 \\
\hline Not employed & 479 & $55.4(51.2$ to 59.7$)$ & 1230 & $56.4(53.2$ to 59.5$)$ & \\
\hline Employed & 326 & $44.6(40.3$ to 48.8$)$ & 866 & $43.6(40.5$ to 46.8$)$ & \\
\hline Immigration status & & & & & $<.001$ \\
\hline No (born in the US) & 552 & $77.2(73.1$ to 81.4$)$ & 1544 & $84.4(82.3$ to 86.4$)$ & \\
\hline Yes: immigrant & 253 & 22.8 (18.6 to 26.9$)$ & 552 & $15.6(13.6$ to 17.7$)$ & \\
\hline Perceived English proficiency & & & & & .379 \\
\hline Comfortable & 486 & $63.7(58.9$ to 68.5$)$ & 1230 & $61.3(58.6$ to 64.1$)$ & \\
\hline Not comfortable & 319 & $36.3(31.5$ to 41.1$)$ & 866 & 38.7 (35.9 to 41.4$)$ & \\
\hline Census region, No. (\%) & & & & & .606 \\
\hline Northeast & 130 & $16.2(12.9$ to 19.6$)$ & 315 & $15.6(13.3$ to 17.9$)$ & \\
\hline Midwest & 135 & $20.9(17.0$ to 24.8$)$ & 382 & $23.5(20.4$ to 26.5$)$ & \\
\hline South & 324 & $41.2(36.6$ to 45.7$)$ & 882 & $41.3(38.1$ to 44.5$)$ & \\
\hline West & 216 & $21.7(18.4$ to 25.1$)$ & 517 & $19.6(17.3$ to 21.9$)$ & \\
\hline Health insurance, No. (\%) & & & & & .252 \\
\hline Private & 386 & $56.7(52.3$ to 61.1$)$ & 1054 & $60.1(57.3$ to 62.9$)$ & \\
\hline Public & 351 & $37.6(33.3$ to 41.8$)$ & 852 & 33.8 (31.1 to 36.6$)$ & \\
\hline Uninsured & 68 & $5.7(4.0$ to 7.4$)$ & 190 & $6.1(4.8-7.3)$ & \\
\hline General health status & & & & & .879 \\
\hline Fair to poor & 324 & 34.3 (30.3 to 38.2$)$ & 836 & $34.6(31.9$ to 37.3$)$ & \\
\hline
\end{tabular}




\begin{tabular}{|c|c|c|c|c|c|}
\hline & \multicolumn{2}{|c|}{ Teach-Back } & \multicolumn{2}{|c|}{ Non-Teach-Back } & \multirow[b]{2}{*}{$P$-Value } \\
\hline & No. & $\%(95 \% \mathrm{CI})^{*}$ & No. & $\%(95 \% \mathrm{CI})^{*}$ & \\
\hline Excellent to good & 481 & $65.7(61.8$ to 69.7$)$ & 1258 & $65.4(62.7$ to 68.1$)$ & \\
\hline Hearing handicap & & & & & .104 \\
\hline No problem & 705 & $84.3(81.2$ to 87.5$)$ & 1864 & $87.1(84.9$ to 89.3$)$ & \\
\hline Having a problem with hearing & 100 & $15.7(12.5$ to 18.8$)$ & 232 & $12.9(10.7$ to 15.1$)$ & \\
\hline Current smoking & & & & & .602 \\
\hline No & 659 & $84.7(81.5$ to 87.9$)$ & 1772 & $85.6(83.5$ to 87.8$)$ & \\
\hline Yes & 132 & $15.3(12.1$ to 18.5$)$ & 291 & $14.4(12.2$ to 16.5$)$ & \\
\hline Obesity (BMI $\geq 30 \mathrm{~kg} / \mathrm{m}^{2}$ ) & & & & & .824 \\
\hline No & 359 & $43.9(39.1$ to 48.6$)$ & 920 & $43.3(40.3$ to 46.2$)$ & \\
\hline Yes & 438 & $56.1(51.4$ to 60.9$)$ & 1147 & $56.7(53.8$ to 59.7$)$ & \\
\hline Hypertension & & & & & .822 \\
\hline No & 188 & $24.5(20.7$ to 28.3$)$ & 489 & $24.1(21.5$ to 26.7$)$ & \\
\hline Yes & 617 & $75.5(71.7$ to 79.3$)$ & 1607 & $75.9(73.3$ to 78.5$)$ & \\
\hline Hyperlipidemia & & & & & .136 \\
\hline No & 251 & $31.4(27.2$ to 35.5$)$ & 598 & $27.8(25.3$ to 30.3$)$ & \\
\hline Yes & 554 & $68.6(64.5$ to 72.8$)$ & 1498 & $72.2(69.7$ to 74.7$)$ & \\
\hline Asthma & & & & & .919 \\
\hline No & 689 & $86.7(83.7$ to 89.7$)$ & 1810 & $86.5(84.7$ to 88.3$)$ & \\
\hline Yes & 116 & $13.3(10.3$ to 16.3$)$ & 286 & $13.5(11.7$ to 15.3$)$ & \\
\hline COPD & & & & & .577 \\
\hline No & 760 & $94.2(92.0$ to 96.4$)$ & 1983 & $93.4(91.8$ to 95.0$)$ & \\
\hline Yes & 45 & $5.8(3.6$ to 8.0$)$ & 113 & $6.6(5.0$ to 8.2$)$ & \\
\hline $\begin{array}{c}\text { Time since diabetes diagnosis, } \\
\text { years, Median (IQR) }\end{array}$ & & $7(3$ to 13$)$ & & $7(3$ to 14$)$ & .345 \\
\hline DM care: lifestyle modifications & & & & & .298 \\
\hline No & 167 & $18.9(15.4$ to 22.3$)$ & 474 & $21.2(19.0$ to 23.5$)$ & \\
\hline Yes & 638 & $81.1(77.7$ to 84.6$)$ & 1622 & $78.8(76.5$ to 81.0$)$ & \\
\hline DM care: antidiabetic medications & & & & & .083 \\
\hline No & 140 & $17.5(14.5$ to 20.4$)$ & 402 & 20.9 (18.6 to 23.2$)$ & \\
\hline Yes & 665 & $82.5(79.6$ to 85.5$)$ & 1694 & 79.1 (76.8 to 81.4$)$ & \\
\hline DM care: insulin injections & & & & & .717 \\
\hline No & 562 & $71.6(67.4$ to 75.8$)$ & 1495 & 70.7 (68.2 to 73.3$)$ & \\
\hline Yes & 243 & $28.4(24.2$ to 32.6$)$ & 601 & $29.3(26.7$ to 31.8$)$ & \\
\hline
\end{tabular}

Abbreviations: BMI, body mass index; COPD, chronic obstructive pulmonary disease; DM, diabetes mellitus; GED, general educational development; IQR, interquartile range; CI, confidence interval.

*Estimates were weighted to be nationally representative using recommended stratification, clustering, and weighting by Agency for Healthcare Research and Quality.

${ }^{\dagger}$ Other includes non-Hispanic Asians/Pacific Islanders, Alaskan/American Natives, and other multiple races.

${ }^{\ddagger}$ Family income level was defined based on Federal Poverty Level [FPL] $<100 \%$ as poor income, FPL $100 \%-200 \%$ as low income, FPL 200\%-400\% middle income, and FPL > 400\% high income.

having hospitalization in Year 1 (baseline year), history of cancer or pregnancy at the time of the survey were excluded due to the possible severity of the condition and unusual patterns of health services utilization (eg, hospitalization for delivery). ${ }^{15}$ The final study sample included 2901 (weighted sample of $10,121,276)$ individuals met the study inclusion and exclusion criteria. Figure 1 presents the study cohort selection process.

\section{Measures}

Primary Exposure: Teach-Back Experience

The primary independent variable was the patient teach-back experience at the baseline year. Criteria and procedures to define the teach-back experience are described in detail elsewhere. ${ }^{15,32}$ Briefly, a 2-step approach was employed to identify patients with teach-back experience during their visits to any type of health care provider: 1) patients perceived 
Figure 1. Analytic cohort selection. Abbreviation: MEPS, Longitudinal Medical Expenditure Panel Survey.

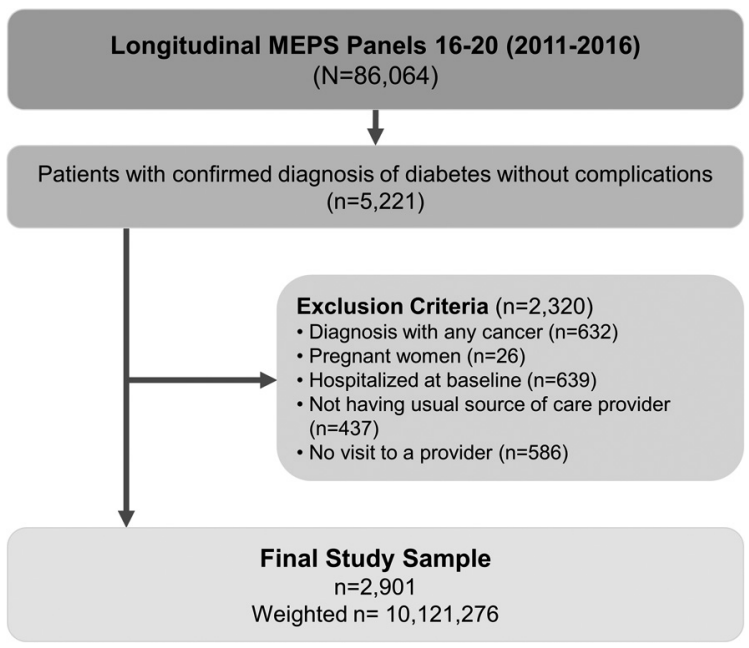

instructions given from health providers to be easy to understand, and 2) those asked to describe how to follow the instructions given. The study sample included those who had 1 or more visits to their usual source of providers at the baseline year. Given that the teach-back questions were a summative assessment of all clinical encounters in the past 12 months, we made the conservative assumption that a patient received consistent teach-back only if he or she responded "always" to the questions and we defined as nonteach-back if responded otherwise.

\section{Primary Outcomes: Complications, Hospitalization, and Health Expenditures}

Primary outcomes for this study included diabetesrelated complications, hospitalization, and total health expenditure. Diabetic complications included any cardiovascular disease (CVD; coronary heart disease, myocardial infarction, angina, cardiac dysrhythmias, congestive heart failure, cerebrovascular disease, and other heart diseases), eye, and kidney problems. Any diagnosis of those complications during the followup (Year 2) was measured using self-reported questions first and supplemented by medical records in the Medical Condition Files using ICD-9-CM or ICD-10-CM codes. Beginning in 2016, ICD-9-CM codes are no longer used in the MEPS and participants' medical conditions are coded using ICD-10CM. The study participants in the Panel 20 (2015 to 2016 cohort) were in this transition, and thus, their Year-2 outcomes were measured using corresponding
ICD-10-CM codes. Hospitalization or any inpatient admission in Year 2 was measured if participants had 1 or more events (for any cause). Condition-specific admission was identified using a similar approach using ICD-9-CM or ICD-10-CM. A full list of aggregated ICD-9-CM and ICD-10-CM conditions to specify these outcomes is provided in Appendix Table 1. Total health expenditure was defined as the sum of direct payments for care provided during the year. Both Year-1 and Year-2 total expenditures were adjusted for inflation and expressed in 2017 US dollars. $^{33}$

\section{Other Covariates}

Patient characteristics included self-reported sociodemographic and health-related information: age (18 to 49 years, 50 to 59 years, 60 to 64 years, 65 to 69 years, and 70+ years), sex, race/ethnicity (nonHispanic White, non-Hispanic Black, Hispanic, and Other [Asian/Pacific Islander, American Indian/ Alaskan Native, other multiple races]), foreign-born status, education (less than high school, high school diploma/general educational development), family income (based on federal poverty level [FPL] $<100 \%$ as poor income, $\mathrm{FPL} 100 \%$ to $200 \%$ as low income, FPL $200 \%$ to $400 \%$ middle income, and FPL > 400\% high income), census region (Northeast, Midwest, South, and West), health insurance type (any private, public, and uninsured), general health status (poor/fair and good/excellent), and current smoking, obesity (self-reported body mass index $>29.9 \mathrm{~kg} / \mathrm{m}^{2}$ ), and comorbid conditions (hypertension, hyperlipidemia, and chronic obstructive pulmonary disease, and asthma). The comorbid conditions were derived from the questions asking, "Has your doctor/health provider ever told you that you have a condition?" for each corresponding condition. Current diabetes care and treatment information were also included: whether was being treated with lifestyle modification, any medication, or insulin injections. Detailed specifications of variables and measures we used for this study are available in Appendix Table 2.

\section{Statistical Analysis}

Survey-design adjusted Wald $F$ tests were used to summarize study sample characteristics. Multivariable logistic models were used to determine the association between teach-back experience in Year 1 and binary outcomes, whether having complications and hospitalization in Year 2. Total expenditures were estimated using generalized linear models with log link and $\gamma$ 
Table 2. Associations between Teach-Back Experience and Patient Health Outcomes

\begin{tabular}{|c|c|c|c|c|c|c|c|}
\hline & \multicolumn{2}{|c|}{ Teach-Back } & \multirow[b]{3}{*}{$P$-Value } & \multirow{2}{*}{\multicolumn{4}{|c|}{ Teach-Back versus Non-Teach-Back }} \\
\hline & \multirow{2}{*}{$\begin{array}{c}\text { Yes } \\
\%,(95 \% \mathrm{CI})\end{array}$} & \multirow{2}{*}{$\begin{array}{c}\text { No } \\
\%,(95 \% \mathrm{CI})\end{array}$} & & & & & \\
\hline & & & & $\begin{array}{c}\text { Crude Odds Ratio } \\
\text { (OR) }\end{array}$ & $\begin{array}{c}P- \\
\text { Value }\end{array}$ & Adjusted OR* & $P$-Value \\
\hline \multicolumn{8}{|l|}{ Complication } \\
\hline Any & $14.0(10.9$ to 17.1$)$ & $17.7(15.8$ to 19.7$)$ & .042 & $0.74(0.56-0.99)$ & .045 & $0.70(0.52-0.96)$ & .026 \\
\hline CVDs† & $6.7(4.5$ to 8.9$)$ & $8.3(6.7$ to 9.8$)$ & .281 & $0.77(0.50-1.19)$ & .232 & $0.71(0.45-1.11)$ & .133 \\
\hline $\begin{array}{l}\text { Kidney } \\
\text { problem }\end{array}$ & $3.1(1.4-4.7)$ & $4.9(3.9-5.9)$ & .052 & $0.63(0.36-1.10)$ & .102 & $0.62(0.33-1.14)$ & .123 \\
\hline Eye problem & $5.5(3.6$ to 7.5$)$ & $7.1(5.6$ to 8.7$)$ & .200 & $0.77(0.50-1.19)$ & .242 & $0.76(00.49-1.18)$ & .217 \\
\hline \multicolumn{8}{|l|}{ Hospitalization } \\
\hline All cause & $5.4(3.6$ to 7.2$)$ & $7.8(6.4$ to 9.3$)$ & .051 & $0.73(0.49-1.10)$ & .133 & $0.72(0.47-1.09)$ & .123 \\
\hline DM specific & $2.0(1.1$ to 2.8$)$ & $2.9(1.8-4.0)$ & .085 & $0.59(0.30-1.17)$ & .131 & $0.58(0.29-1.14)$ & .112 \\
\hline $\begin{array}{l}\text { Complication } \\
\text { related }\end{array}$ & 2.4 (1.2 to 3.7$)$ & $4.6(3.5-5.7)$ & .011 & $0.53(0.30-0.94)$ & .031 & $0.51(0.29-0.88)$ & .015 \\
\hline
\end{tabular}

Abbreviations: CVD, cardiovascular disease; DM, diabetes mellitus.

*Adjusted model included age, sex, race/ethnicity, foreign-born status, education, family, census, health insurance type, general health status, and current smoking, obesity, number of comorbid conditions, and current diabetes management items: whether having lifestyle modification, antidiabetic drugs, and insulin injections.

${ }^{\dagger}$ Includes coronary heart disease, angina, myocardial infarction, other heart diseases.

OR, odds ratio; CI, confidence interval.

distribution to address the positive skewness of the health care cost data. ${ }^{34}$ Differences in total expenditures between Year 1 and Year 2 were then compared using ordinary least-squares regression models. The models were adjusted for all sociodemographic and clinical characteristics listed above as covariates, consistent with previous studies using MEPS. ${ }^{34-36}$ All analyses incorporated longitudinal MEPS survey weights and standard errors accounted using the Taylor-series linearization method in SPSS 24 Complex Survey (IBM Corp., Armonk, NY) and SAS 9.4 (SAS Institute, Cary, NC), as recommended. ${ }^{29}$

\section{Results}

Of 2901 individuals living with diabetes (median age [interquartile range; IQR], 60 years [51 to 69 years], $52.6 \%$ female, $59.5 \%$ non-Hispanic White, median time since diabetes diagnosis [IQR], 7 years [3 to 14 years]), $25.0 \%$ (95\% CI, $23.0 \%$ to $26.9 \%$, representing 2.5 million individuals with diabetes) reported consistent patient teach-back experience at the baseline year. Overall, there was not much difference across socioeconomic and health-related characteristics between the teach-back and nonteach-back groups. However, those who were racial/ethnic minorities or immigrants were more likely to have teach-back experience (Table 1).

\section{Diabetic Complications}

During the 1-year followup, 16.8\% (95\% CI, $15.1 \%$ to $18.5 \%$ ) study participants developed diabetic complications. Particularly, CVD accounted for more than $50 \%$ of complications developed during the study period. Compared with patients not having teach-back experience, those having teach-back had lower rates of diabetic complications: for any CVD, $6.7 \%$ versus $8.3 \%$, for kidney problem, $3.1 \%$ versus $4.9 \%$, and an eye problem, $5.5 \%$ versus $7.1 \%$ (Table 2 ). However, these differences were not statistically significant $(P>.05$ for all). When combined (for any complication), there was a significant difference in complications observed (14.0\% vs $17.7 \%, P=.042)$. In adjusted analysis, patients with teach-back experience had a lower likelihood of developing any diabetic complication (adjusted odds ratio [AOR], 0.70; 95\% CI, $0.52-0.96 ; P=.026)$ than those without teach-back.

\section{Hospitalization}

Overall, $6.5 \%$ (95\% CI, $5.4 \%$ to $7.7 \%$ ) of patients were hospitalized for any reason during the 1-year followup. Although patients with teach-back experience had a lower likelihood of hospitalization (AOR, 0.72; 95\% CI, 0.47-1.09) than those without, this difference did not reach statistical significance $(P=.123)$ (Table 2). Similarly, for diabetes-specific 
hospitalization, having teach-back experience was not associated with the likelihood of hospitalization (AOR, 0.58; 95\% CI, 0.29-1.14; $P=.112$ ). However, those with teach-back experience had a lower likelihood of being hospitalized for diabetic complications, mostly for CVD-related (AOR, 0.51; 95\% CI, 0.29-0.88; $P=.015)$.

\section{Health Expenditures}

During the study period, the unadjusted average total health expenditures of the study population increased by $48.2 \%$ from the mean annual expenditure of $\$ 8491$ at the baseline to $\$ 12,581$ in the follow-up year. This increase of $\$ 3090$ was largely driven by hospitalization events (\$2592 per patient, $\$ 20,088$ per episode of hospitalization) and prescription drugs (\$911 per patient; data not shown). Table 3 shows the changes in adjusted total expenditures for patients with teach-back experience relative to their counterparts. In the follow-up year, those having teach-back experience had a significantly smaller increase in adjusted total expenditures of $\$ 1920$ (95\% CI, \$1660 to \$2178) compared with those not having teach-back of \$3639 (95\% CI, $\$ 3466$ to $\$ 3812$; a differential change of $-\$ 1579$ [95\% CI, $-\$ 1717$ to $-\$ 1443$ ]; $P<.001$ ). When extrapolated based on the study population estimates (10.1 million patients with diabetes), these differences translate into aggregate potential savings of $\$ 11.9$ (95\% CI, $\$ 10.9$ to $\$ 13.0$ ) billion from the teach-back implementation in diabetes care.

\section{Discussion}

Using the nationally representative sample of patients with diabetes, we found that patients with teach-back experience were less likely than those without to develop diabetic complications and have hospital admissions related to those conditions. We hypothesize patient teach-back experience may have improved their comprehension of the condition and management skills. These improvements may result in reduced risks for complications and relatedhospitalizations and ultimately leading to a reduction in health expenditures. Previous studies demonstrated that the teach-back intervention reduced the hospitalization risk by $12 \%$ to $36 \%$ among patients with other chronic conditions (eg, heart failure). ${ }^{15,16}$ Evaluating the differential increase in total expenditures during the study period between the teach-back and control groups indicates that, with continuous teach-back use, $\$ 1443$ to $\$ 1717$ could be saved for a patient diagnosed with diabetes without complications. Full implementation of teach-back communication in the current diabetes care would generate annual savings of $\$ 11.9$ billion (by multiplying the estimated 10.1 million with missed opportunity). These estimates are comparable or slightly greater than the potential annual savings from eliminating medication nonadherence ( $\$ 10.1$ in 2017 USD) among all patients with diabetes. ${ }^{37}$

Our findings provide a valuable reference that can be used to strengthen patient education in practice and public health education in various settings. We hope to raise more awareness of the importance and effectiveness of the teach-back among medical school boards, primary care providers, and health educationists. $^{26,27}$ The key impact of teach-back links the implication of effective patient-provider communication and its benefits during the delivery of care and patient disease management. Diabetes is the most common chronic condition and precursor to CVDs and many cancers, top leading causes of

Table 3. Differential Changes in Adjusted Total Medical Expenditure by Teach-Back Experience

Teach-Back

\begin{tabular}{|c|c|c|c|c|}
\hline \multirow{2}{*}{ Total expenditure $^{\dagger}$} & \multirow{2}{*}{$\begin{array}{l}\text { Yes } \\
\text { Mean }(95 \% \text { CI })\end{array}$} & \multirow{2}{*}{$\begin{array}{l}\text { No } \\
\text { Mean }(95 \% \text { CI })\end{array}$} & \multicolumn{2}{|c|}{$\underline{\text { Teach-Back versus Non-Teach-Back }}$} \\
\hline & & & Difference* $^{*}$ & $P$-value \\
\hline Year 1 expenditure & $8162(7790$ to 8535$)$ & 8435 (8173 to 8699$)$ & $-36(-176$ to 105$)$ & .615 \\
\hline Year 2 expenditure & $1,0082$ (9620 to 10544$)$ & $1,2075$ (11743 to 12406$)$ & $-1616(-1801$ to -1430$)$ & $<.001$ \\
\hline Changes between year 1 and year 2 & $1920(1660$ to 2178$)$ & 3639 (3466 to 3812$)$ & $-1579(-1717$ to -1443$)$ & $<.001$ \\
\hline
\end{tabular}

*Adjusted for age, sex, race/ethnicity, foreign-born status, education, family, census, health insurance type, general health status, and current smoking, obesity, number of comorbid conditions, and current diabetes management items: whether having lifestyle modification, antidiabetic drugs, and insulin injections.

${ }^{\dagger}$ Sum of direct payments for care provided during the year, including hospital inpatient care, ambulatory care, other medical services, and out-of-pocket payments.

CI, confidence interval. 
death in the United States. ${ }^{3-6}$ The disease requires patients to actively self manage the condition in their everyday lives. For this reason, the ability to effectively use health information and health care services is of great importance; most importantly, effective patient self-management is closely related to health literacy and their understanding of the condition and treatment. ${ }^{7-11}$ However, there has been a longstanding issue of the disconnect between what delivered in a clinic and what a patient actually does at home. Health care providers, especially in primary care settings, should play a key role in assisting patients and their caregivers in developing their ability to perform self-care management and be successful across the continuum of care. Implementing teach-back as a standard of care and applying to other chronic disease management could hold great promise in improving the overall quality of care delivered and patient population health. Future research should further investigate patient characteristics that can reflect their ability (eg, health literacy) or barriers (eg, patient perception and attitude toward teachback) to effective communication with providers.

Findings from this study also have some implications for policy makers and other stakeholders involved in designing value-based programs. The value-based program models are designed to incorporate patient-centered outcomes to improve the quality of care and incentivize providers in a reliable and effective way. ${ }^{38-40}$ The present study found that the teach-back method during the interaction between a patient and provider achieved favorable patient outcomes. However, only $25 \%$ of the patient population with diabetes had consistent teach-back experience during their visits to care. This information would lend insight into guidelines for clinical practice and highlight the need to include "value-added" clinical processes like teachback communication and patient-provider interaction quality, given a significant link between clinical process and patient outcomes when evaluating performance. If the teach-back implementation is adopted as one of the care process measures, the overall increase in patient-provider interaction quality and patient satisfaction should be achieved effectively and linked to subsequent favorable health outcomes. ${ }^{23,27}$ Wider adoption of teachback or analogous strategy (eg, a follow-up assessment to ensure shared understanding between provider and patient), including standard practice guidelines to promote and incentivize its use, would be promising for both providers and patients in the delivery of care.

There are limitations to this study and caution is required for interpretation of the study findings. First, in the nature of secondary data analysis, we were not able to capture and control for other unmeasured (or unmeasurable) factors that might have caused residual confounding. For example, clinical measures (eg, Hemoglobin A1c control) and quality performance during teach-back (eg, length of teach-back time, question quality, provider attitude and behaviors) were not measurable in the given dataset. How teach-back was performed and in what settings can be valuable information given that care delivery by a provider who is more congruent with clinical guidelines tend to be more patient centered and involves superior communication with a patient. How interactive the communication actually was between patient and provider would be critical to further assess the effectiveness of teach-back implementation. In the same vein, the use of teach-back communication may be subject to selection bias. For example, primary care practices embedded in large health care systems may have more resources for training providers and may also have more resources to implement other aspects of patient-centered care that impact outcomes for their patients. Future research with a more rigorous experimental study design is warranted to control for these possible confounders and confirm the study findings. Third, although the study follow-up period may be too short of capturing diabetes-related complication development, longer duration of diabetes (median, 7 years; IQR, 3 to 14 years) among study participants may have led us to overestimate complication rates during the study period. Forth, given the MEPS sampling design, the findings from this study may not be generalizable to those institutionalized populations (eg, nursing homes, rehabilitation centers, and other long-term facilities). Fifth, patient medical records were obtained from supplementary medical conditions, prescription drug, and inpatient stay data files that were verified from providers and insurers the MEPS respondents used. ${ }^{28}$ However, excessive missing values and unavailability of full ICD-9 and 10 codes (eg, full 5 digits for ICD-9 and 7 digits for ICD-10) are frequently cited limitations of analyzing the MEPS data. Some discrepancies in patient records between national surveys and claims data have also been reported. ${ }^{41}$ Lastly, the majority of information in the MEPS was based on patient self-reported data, which is subject to response and recall biases. 
In summary, teach-back is a simple communication technique to confirm patient understanding by a follow-up assessment asking about what they were told or discussed during their visit to care. Patients with diabetes who reported teach-back experience were less likely to develop diabetic complications, reducing the risk for condition-related hospitalization and total health expenditures. However, patient teach-back is a substantially underused strategy in primary care for those with diabetes, suggesting considerable missed opportunities to enhance the quality of care. For those who are eager to deliver true patient-centered care in practice, it is important to recognize the potentials of this simple assessment during a visit to care for improving patient experience, compliance to treatment, and health outcomes. To establish and maintain an effective, therapeutic patient-provider relationship is the key to success under the ongoing health reform. Further effort is needed to expand and incorporate the teach-back method in the delivery of diabetes care.

To see this article online, please go to: http://jabfm.org/content/ 33/6/903.full.

\section{References}

1. International Diabetes Federation. IDF Diabetes Atlas. 8th Edition. Brussels, Belgium: https:// diabetesatlas.org/; 2017.

2. Boyle JP, Thompson TJ, Gregg EW, Barker LE, Williamson DF. Projection of the year 2050 burden of diabetes in the US adult population: dynamic modeling of incidence, mortality, and prediabetes prevalence. Popul Health Metr 2010;8:29.

3. American Diabetes Association. 2. Classification and Diagnosis of diabetes: standards of medical care in diabetes-2019. Diabetes Care 2019;42:S13-S28.

4. American Diabetes Association. 10. Cardiovascular disease and risk management: standards of medical care in diabetes-2019. Diabetes Care 2019;42: S103-S123.

5. Grundy SM, Benjamin IJ, Burke GL, Chait A, Eckel RH, Howard BV, et al. Diabetes and cardiovascular disease. Circulation 1999;100:1134-46.

6. Peeters PJHL, Bazelier MT, Leufkens HGM, De Vries F, De Bruin ML. The risk of colorectal cancer in patients with type 2 diabetes: associations with treatment stage and obesity. Diabetes Care 2015;38:495-502.

7. American Diabetes Association. 4. Comprehensive medical evaluation and assessment of comorbidities: standards of medical care in diabetes-2019. Diabetes Care 2019;42:S34-S45.
8. American Diabetes Association. 5. Lifestyle Management: Standards of Medical Care in Diabetes-2019. Diabetes Care 2019;42:S46-S60.

9. Conlin PR, Colburn J, Aron D, Pries RM, Tschanz MP, Pogach L. Synopsis of the 2017 U.S. Department of Veterans Affairs/U.S. Department of Defense Clinical Practice Guideline: management of type 2 diabetes mellitus. Ann Intern Med 2017;167:655-10.

10. American Diabetes Association. 1. Improving care and promoting health in populations: standards of medical care in diabetes-2019. Diabetes Care 2019;42:S7-S12.

11. American Diabetes Association. 9. Pharmacologic approaches to glycemic treatment: standards of medical care in diabetes-2019. Diabetes Care 2019;42:S90-S102.

12. Schillinger D, Piette J, Grumbach K, Wang F, Wilson C, Daher C, et al. Closing the loop. Arch Intern Med 2003;163:83-90.

13. Weiss B. Health literacy and patient safety: help patients understand. 2007. Available from: https:// med.fsu.edu/userFiles/file/ahec_health_clinicians_ manual.pdf.

14. Agency for Healthcare Research and Quality. Health Literacy Universal Precautions Toolkit, 2nd Ed. 2015. Available from: http://www.ahrq.gov/professionals/ quality-patient-safety/quality-resources/tools/literacytoolkit/healthlittoolkit2-tool5.html. Accessed February 26, 2018.

15. Hong YR, Cardel M, Suk R, Vaughn IA, Deshmukh AA, Fisher CL, et al. Teach-back experience and hospitalization risk among patients with ambulatory care sensitive conditions: a matched cohort study. J Gen Intern Med 2019;34:2176-84.

16. Peter D, Robinson P, Jordan M, Lawrence S, Casey K, Salas-Lopez D. Reducing readmissions using teach-back: enhancing patient and family education. J Nurs Adm 2015;45:35-42.

17. Darcy AM, Murphy GA, DeSanto-Madeya S. Evaluation of discharge telephone calls following total joint replacement surgery. Orthop Nurs 2014;33: 188-95.

18. White M, Garbez R, Carroll M, Brinker E, HowieEsquivel J. Is "teach-back" associated with knowledge retention and hospital readmission in hospitalized heart failure patients? J Cardiovasc Nurs 2013;28:137-46.

19. Hong YR, Samuels SK, Huo J, Lee N, Mansoor H, Duncan RP. Patient-centered care factors and access to care: a path analysis using the Andersen behavior model. Public Health 2019;171:41-9.

20. Hong YR, Tauscher J, Cardel M. Distrust in health care and cultural factors are associated with uptake of colorectal cancer screening in Hispanic and Asian Americans. Cancer 2018;124:335-45.

21. Mainous AG, Baker R, Love MM, Gray DP, Gill JM. Continuity of care and trust in one's physician: 
evidence from primary care in the United States and the United Kingdom. Fam Med 2001;33:22-7.

22. Jager AJ, Wynia MK. Who gets a teach-back? Patient-reported incidence of experiencing a teachback. J Health Commun 2012;17:294-302.

23. Hong YR, Jo A, Cardel M, Huo J, Mainous AG. Patient-provider communication with teach-back, patient-centered diabetes care, and diabetes care education. Patient Educ Couns 2019;11-3.

24. Mika VS, Wood PR, Weiss BD, Treviño L. Ask me 3: improving communication in a Hispanic pediatric outpatient practice. Am J Health Behav 2007;31:115-21.

25. Kornburger C, Gibson C, Sadowski S, Maletta K, Klingbeil C. Using "teach-back" to promote a safe transition from hospital to home: an evidence-based approach to improving the discharge process. J Pediatr Nurs 2013;28:282-91.

26. Yen PH, Leasure AR. Use and effectiveness of the teach-back method in patient education and health outcomes. Fed Pract 2019;36:284-9.

27. Centrella-Nigro AM, Alexander C. Using the teach-back method in patient education to improve patient satisfaction. J Contin Educ Nurs 2017;48:4752.

28. Cohen JW, Cohen SB, Banthin JS. The Medical Expenditure Panel Survey: a national information resource to support healthcare cost research and inform policy and practice. Med Care 2009;47:S44-50.

29. Agency for Health, Research and Policy. MEPS Panel 20 Longitudinal Data File. 2018. Available from: https://meps.ahrq.gov/data_stats/download_ data_files_detail.jsp?cboPufNumber=HC-193. Accessed July 2019.

30. Kirkman MS, Rowan-Martin MT, Levin R, Fonseca VA, Schmittdiel JA, Herman WH, et al. determinants of adherence to diabetes medications: findings from a large pharmacy claims database. Diabetes Care 2015;dc142098.

31. Agency for Healthcare Research and Quality. MEPS HC-190: 2016 Medical Conditions File. 2019. Available from: https://meps.ahrq.gov/mepsweb/data_ stats/download_data_files_detail.jsp?cboPufNumber= HC-190. Accessed July 26, 2019.
32. Agency for Healthcare Research and Quality. Use the teach-back method: tool 5. health literacy universal precautions toolkit. 2nd Ed. 2015. Available from: https://www.ahrq.gov/professionals/qualitypatient-safety/quality-resources/tools/literacytoolkit/healthlittoolkit2-tool5.html. Accessed January 23, 2019.

33. Bureau of Labor Statistics. Medical care in Consumer Price Index. 2019. Available from: http://data.bls.gov/timeseries/CUUR0000SAM? output_view=pct_12mths. Accessed May 18, 2019.

34. Deb P, Norton EC. Modeling health care expenditures and use. Annu Rev Public Health 2018;39:489-505.

35. Hong YR, Sonawane K, Larson S, Mainous AG, Marlow NM. Impact of provider participation in ACO programs on preventive care services, patient experiences, and health care expenditures in US adults aged 18-64. Med Care 2018;56:711-8.

36. Agency for Healthcare Research and Quality. MEPS topics: medical expenditures. 2009. Available from: https://meps.ahrq.gov/mepsweb/data_stats/ MEPS_topics.jsp?topicid=33Z-1. Accessed November 4, 2016.

37. Jha AK, Aubert RE, Yao J, Teagarden JR, Epstein RS. Greater adherence to diabetes drugs is linked to less hospital use and could save nearly $\$ 5$ billion annually. Health Aff (Millwood) 2012;31:1836-46.

38. Haley DR, Zhao M, Spaulding A. Hospital valuebased purchasing and 30-day readmissions: are hospitals ready? Nurs Econ 2016;34:110-6.

39. United States Government Accountability Office. Hospital value-based purchasing: initial results show modest effects on Medicare payments and no apparent change in quality-of-care trends report. 2015. Washington, DC. Available from: https:// www.gao.gov/products/GAO-16-9.

40. Hong YR, Nguyen O, Yadav S, et al. Early performance of hospital value-based purchasing program in Medicare. Med Care 2020;58:734-43.

41. Aizcorbe A, Liebman E, Pack S, Cutler DM, Chernew ME, Rosen AB. Measuring health care costs of individuals with employer-sponsored health insurance in the U.S.: A comparison of survey and claims data. Stat J IAOS 2012;28:43-51. 


\section{Appendix A. Identification of Medical Conditions}

Table A-1. AHRQ Clinical Classification Category (CCC) and ICD-9 and 10-CM Codes Defining Medical Conditions

\begin{tabular}{lcc}
\hline CCC Codes & Conditions & Aggregated ICD-9-CM Codes \\
\hline Diabetes & & \\
49 & & \\
& Diabetes mellitus & 249002500025001790279021 \\
& without & 790227902979157916 V4585 \\
50 & Complication & 2490124910249112492024921 \\
& Diabetes mellitus & 24930249312494024941 \\
& with complications & 24950249512496024961 \\
& 24970249712498024981 \\
& 24990249912500225003 \\
& 25010250112501225013 \\
& 25020250212502225023 \\
& 25030250312503225033 \\
& 25040250412504225043 \\
& 25050250512505225053 \\
& 25060250612506225063 \\
& 25070250712507225073 \\
& 25080250812508225083 \\
& 25090250912509225093
\end{tabular}

Cardiovascular Diseases

$100 \quad \begin{gathered}\text { Acute myocardial } \\ \text { infarction }\end{gathered}$

Other endocrine disorders

infarction
251025112512251325142515

2518251925202520025201

2520225208252125282529

253025312532253325342535

253625372538253925402541

254825492550255125510

255112551225513255142552

2553255425541255422555

255625582559256025612562

256325642568256925702571

257225782579258025801

258125882589259025912592

2593259425952595025951

25952259825997946

27202721272227232724

41004100041001410024101 410104101141012410241020 410214102241034103041031
E089 E099 E109 E119 E139 R7301 R7302 R7303 R7309R739 R81 R824 Z4681 Z9641

E0800 E0801 E0810 E0811 E0821 E0822 E0829 E08311 E08319 E08321 E08331 E08341 E8535E0836 E0837 × 1 E0837 $\times 2 \mathrm{E} 0837 \times 3 \mathrm{E} 0837 \times 9 \mathrm{E} 0839 \mathrm{E} 0840$ E0841 E0842 E0843E0844 E0849 E0851 E0852 E0859 E08610 E08618 E0862 E0863 E0864 E0865 E0869 E088 E0900 E0901 E0910 E0911 E0921 E0922 E0929 E0931 E0932 E09329 E09331 E09339 E09341 E09349 E09351 E093521 E093531 E09354 E09355 E09359 E093 6E0937 × 1 E0937 × 2 $\mathrm{E} 0937 \times 3 \mathrm{E} 0937 \times 9 \mathrm{E} 0939 \mathrm{E} 0940$ E0941 E0942 E0943 E0944 E0949 E0951 E0952 E0959 E09610 E09618 E0962 E0963 E09641 E09649 E0965 E0969 E098 E1010 E1011 E1021 E1022 E1029 E1031 E1032 E1033 E1034 $\mathrm{E} 1035 \mathrm{E} 1036 \mathrm{E} 1037 \times 1 \mathrm{E} 1037 \times 2$ $\mathrm{E} 1037 \times 3 \mathrm{E} 1037 \times 9 \mathrm{E} 1039 \mathrm{E} 1040$ E1041 E1042 E1043 E1044 E1049 E1051 E1052 E1059 E1061 E1062 E1063 E1064 E1065 E1069 E108 E110 E111 E112 E113 E1140 E1151 E1152 E1159E1161 E1162 E1163 E1164 E1169 E118 E1300 E1310 E1311 E1321 E1322 E1329 E1331 E1332 E1333 E13341 E13351 E13352 E13353 E13354 E13355 E13359 E1336 E1337 × 1 E1337 × 2 $\mathrm{E} 1337 \times 3 \mathrm{E} 1337 \times 9 \mathrm{E} 1339 \mathrm{E} 1340$ E1341E1342 E1343 E1344 E1349 E1351 E1352 E1359 E13610 E13618 E1362 E1363 E13641E13649 E1365 E1369 E138 G3289

E15 E160 E161 E162 E163 E164 E168 E169 E200 E208 E209 E210 E211 E212 E213 E214 E215 E220 E221 E222 E228 E229 E230 E231 E232E233E236E237 E240 E241 E242 E243 E244E248E249 E250 E258 E259 E260 E2602 E2609 E261 E2681 E2689 E269 E270 E271 E272 E273 E274 E2749 E275 E278 E279 E280 E281 E282 E288 E289 E290 E291E298 E299 E300 E301 E308 E309 E310 E311 E312 E318 E319 E320 E321 E328 E329 E340 E341 E342 E343 E344 E3450 E3451 E3452 E348 E349 E35 Z9483 Z9649

E780 E7800 E7801 E781 E782 E783 E784 E785

I2101 I2102 I2109 I2111 I2119 I2121 I2129 I213 I214I219 I21A1 I21A9 I220 I221 I222 I228 I229 


\begin{tabular}{|c|c|c|c|}
\hline CCC Codes & Conditions & Aggregated ICD-9-CM Codes & Aggregated ICD-10-CM Codes \\
\hline & & $\begin{array}{l}410324104410404104141042 \\
41054105041051410524106 \\
410604106141062410741070 \\
410714107241084108041081 \\
410824109410904109141092\end{array}$ & \\
\hline 101 & $\begin{array}{l}\text { Coronary } \\
\text { atherosclerosis and } \\
\text { other heart disease }\end{array}$ & $\begin{array}{l}4110411141184118141189 \\
412413041314139414041400 \\
414014140641484149 \text { V4581 } \\
\text { V4582 }\end{array}$ & $\begin{array}{l}\text { I200 I201 I208 I209 I237 I240 I241 I248 } \\
\text { I249 I2510 I2511 I25111 I25118 I25119 } \\
\text { I252 I255 I256 I2575 I25811 I2582 I2583 } \\
\text { I2584 I2589 I259 Z951 Z955 Z9861 }\end{array}$ \\
\hline 102 & $\begin{array}{l}\text { Nonspecific chest } \\
\text { pain }\end{array}$ & 786507865178659 & R072 R0782 R0789 R079 \\
\hline 103 & $\begin{array}{l}\text { Pulmonary heart } \\
\text { disease }\end{array}$ & $\begin{array}{l}41504151415124151341519 \\
\quad 416041614162416841694170 \\
417141784179\end{array}$ & $\begin{array}{l}\text { I2601 I2602 I2609 I2690 I2692 I2699 I270 } \\
\text { I271 I272 I2720 I2721 I2722 I2723 I2724 } \\
\text { I2729 I2781 I2782 I2783 I2789 I279 I280 } \\
\text { I281 I288 I289 Z86711 }\end{array}$ \\
\hline 104 & $\begin{array}{l}\text { Other and ill-defined } \\
\text { heart disease }\end{array}$ & $\begin{array}{l}414104141141412414194291 \\
429242934295429642971 \\
429794298142982429894299\end{array}$ & $\begin{array}{l}\text { I231 I232 I233 I234 I235 I236 I238 I253 } \\
\text { I2541 I2542 I510 I511 I512 I513 I515 } \\
\text { I517 I5181 I5189 I519 I52 }\end{array}$ \\
\hline 105 & Conduction disorders & $\begin{array}{c}426042610426114261242613 \\
4262426342644265042651 \\
42652426534265442664267 \\
4268142682426894269 \text { V450 } \\
\text { V4500 V4501 V4502 V4509 } \\
\text { V533 V5331 V5332 V5339 }\end{array}$ & $\begin{array}{l}\text { I440 I441 I442 I4430 I4439 I444 I445 } \\
\text { I4460 I4469 I447 I450 I4510 I4519 I452 } \\
\text { I453 I454 I455 I456 I4581 I4589 I459 } \\
\text { Z4501 Z45018 Z4502 Z4509 Z950 } \\
\text { Z95810 }\end{array}$ \\
\hline 106 & Cardiac dysrhythmias & $\begin{array}{c}4270427142724273142732 \\
42760427614276942781 \\
42789427978507851\end{array}$ & $\begin{array}{l}\text { I470 I471 I472 I479 I480 I481 I482 I483 } \\
\text { I484 I4891 I4892 I491 I492 I493 I4940 } \\
\text { I4949 I495 I498 I499 R000 R001R002 }\end{array}$ \\
\hline 107 & $\begin{array}{l}\text { Cardiac arrest and } \\
\text { ventricular } \\
\text { fibrillation }\end{array}$ & 42741427424275 & I462 I468 I469 I4901 I4902 \\
\hline 108 & $\begin{array}{l}\text { Congestive heart } \\
\text { failure; } \\
\text { nonhypertensive }\end{array}$ & $\begin{array}{l}398914280428142820 \\
\quad 4282142822428234283042831 \\
428324283342840 \\
4284142842428434289\end{array}$ & $\begin{array}{l}\text { I0981 I501 I502' I5021 I5022 I5023I5 03' } \\
\text { I5031 I5032 I5033 I504 I5041 I5042 } \\
\text { I5043 I5081 I5082 I5083 I5084 I5089 } \\
\text { I509 }\end{array}$ \\
\hline 109 & $\begin{array}{l}\text { Acute } \\
\text { cerebrovascular } \\
\text { disease }\end{array}$ & $\begin{array}{l}34660346613466234663430431 \\
4320432143294330143311 \\
433214333143381433914340 \\
434004340143414341043411 \\
43494349043491436\end{array}$ & $\begin{array}{l}\text { G43601 G43609 G43611 G43619 I6000 } \\
\text { I6001 I6002 I6010 I6011 I6012 I602 } \\
\text { I6020 I6021I6022 I6030 I6031 I6032I604 } \\
\text { I6050 I6051 I6052 I606 I607 I608 I609 } \\
\text { I610 I611 I612 I613I614I615 I616 I618 } \\
\text { I619 I6200 I6300 I6310 I6320 I6330 } \\
\text { I6340 I6350 I636 I638 I639 I6601 I6602 } \\
\text { I6603 I6609 I6611 I6612 I6613 I6619 } \\
\text { I6621 I6622 I6623 I6629 I663 I668 I669 } \\
\text { R297 R29710 R29720 R29730 R29740 } \\
\text { R29741 R29742 }\end{array}$ \\
\hline 110 & $\begin{array}{l}\text { Occlusion or stenosis } \\
\text { of precerebral } \\
\text { arteries }\end{array}$ & $\begin{array}{l}4330433004331433104332 \\
43320433343330433843380 \\
433943390\end{array}$ & $\begin{array}{l}\text { I6501I6502I6503I6509 } \\
\text { I651I6521I6522I6523 I6529I658I659 }\end{array}$ \\
\hline 111 & $\begin{array}{l}\text { Other and ill-defined } \\
\text { cerebrovascular } \\
\text { disease }\end{array}$ & $\begin{array}{l}437043714373437443754376 \\
\quad 437743784379\end{array}$ & $\begin{array}{l}\text { G460 G461 G462 G463 G464 G465 G466 } \\
\text { G467 G468 I671 I672 I675 I676 I677 } \\
\text { I6781 I6782 I6783 I67841 I67848 I6789 } \\
\text { I679 I680 I682 I688 }\end{array}$ \\
\hline 112 & $\begin{array}{l}\text { Transient cerebral } \\
\text { ischemia }\end{array}$ & 435043514352435343584359 & G450 G451 G452 G453 G454 G458 G459 \\
\hline 113 & $\begin{array}{l}\text { Late effects of } \\
\text { cerebrovascular } \\
\text { disease }\end{array}$ & $\begin{array}{l}4384380438104381143812 \\
438134381443814382043821 \\
4382243830438314383243840 \\
43841438424385043851 \\
43852438534386438743881 \\
43882438834388443885 \\
438894389\end{array}$ & $\begin{array}{l}\text { I6900 I6901 I69020 I69031 I69041 I69042 } \\
\text { I69043 I69044 I69049 I69051 I69052 } \\
\text { I69053 I69054 I69059 I69061 I69062 } \\
\text { I69063 I69064 I69065 I69069 I69090 } \\
\text { I69091 I69092 I69093 I69098 I6910 } \\
\text { I6911 I6920 I6930 I6980 I6981 I69810 } \\
\text { I6990I6991 }\end{array}$ \\
\hline
\end{tabular}


Table A-1. Continued

\begin{tabular}{|c|c|c|c|}
\hline CCC Codes & Conditions & Aggregated ICD-9-CM Codes & Aggregated ICD-10-CM Codes \\
\hline 114 & $\begin{array}{l}\text { Peripheral and } \\
\text { visceral } \\
\text { atherosclerosis }\end{array}$ & $\begin{array}{l}4400440144024402044021 \\
44022440234402944044408 \\
44094439557055715579\end{array}$ & $\begin{array}{l}\text { I700 I701 I702 I708 I7090 I7091 I7092 } \\
\text { I739 K550 K551 K558 K559 }\end{array}$ \\
\hline 115 & $\begin{array}{l}\text { Aortic; peripheral; } \\
\text { and visceral artery } \\
\text { aneurysms }\end{array}$ & $\begin{array}{l}441044100441014410244103 \\
441144124413441444154416 \\
441744194420442144224423 \\
44281442824428344284 \\
442894429443214432244323 \\
44324443294477044771 \\
4477244773\end{array}$ & $\begin{array}{l}\text { I670 I710 I720I721 I722 I723 I724 I725 } \\
\text { I726 I728 I729 I777 I778 I790 }\end{array}$ \\
\hline 116 & $\begin{array}{l}\text { Aortic and peripheral } \\
\text { arterial embolism } \\
\text { or thrombosis }\end{array}$ & $\begin{array}{l}444094441444214442244481 \\
\quad 444894449445014450244581 \\
44589\end{array}$ & $\begin{array}{l}\text { I7401 I7409 I7410 I7411 I7419 I742 I743 } \\
\text { I744 I745 I748 I749 I7501 I75021 I75022 } \\
\text { I75023 I75029 I7581 I7589 }\end{array}$ \\
\hline 117 & $\begin{array}{l}\text { Other circulatory } \\
\text { disease }\end{array}$ & $\begin{array}{l}44304431443814438244389 \\
4460446144624462044621 \\
446294463446444654466 \\
446744704471447244734474 \\
447544764478447944804481 \\
448945804581458845894590 \\
4598945997859 \\
7943079431794397962 \mathrm{~V} 125\end{array}$ & $\begin{array}{l}\text { I7300 I731 I7381 I7389 I770 I771 I772 } \\
\text { I773 I774 I775 I776 I7789 I779 I780 } \\
\text { I781 I788 I789 I791 I798 I950 I951 } \\
\text { I9589 I959 I998 } \\
\text { I999 M310 R030 R031 R0989 R58 } \\
\text { Z8673 Z8674 Z8679 Z941 Z943 Z95811 } \\
\text { Z95820 Z95828 Z959 Z9862 }\end{array}$ \\
\hline
\end{tabular}

Phlebitis; thrombophlebitis and thromboembolism
V1250 V1253 V1254 V1259 V151 V421 V432 V4321 V4322 V434 V717

45104511145119451245181 451824518345184451894519 452453045314532453345340 453414534245351453524536 45371453724537345374 453754537645377453794538 4538245386453874539 V1251 V1252 V1255
Kidney Problem 158

Eye Problem 87
Chronic renal failure
58558535854585558565859 7925 V420 V451 V560 V561 V562 V5631 V5632 V568

3610036101361023610336104 36105361063610736110 36111361123611336114 361193612361303613136132 361333618136189361936201 36202362033620436205 36206362073621036211 36212362133621436215 36216362173621836221 36229362303623136232 36233362343623536236
I8000 I801 I80201 I80202 I80203 I80209 I8021 I8022 I8023 I8029 I803 I808 I809I81 I820 I821 I82290 I82291 I823 I824 I824Y1I824Y2I824Y3 I824Y9 I824Z1I824Z2 I824Z3 824Z9 I82501 I82502 I82503 I82509 I82511 I82512 I82513 I82519 I82521 I82522 I82523 I82529 I82531 I82532 I82533 I82539 I82541 I82542 I82543 I82549 I82591 I82592 I82593 I82599 I825Y1 I825Y2 I825Y3 I825Y9 I825Z1I825Z2 I825Z3 I825Z9 I82601 I82602 I82603 I82609 I82611 I82612 I82613 I82619 I82621 I82622 I82623 I82629 I82701 I82702 I82703 I82709 I82711 I82712 I82713 I82719 I82721 I82722 I82723 I82729 I82811 I82812 I82813 I82819 I82890 I82891 I8290 I8291 I82A11 I82A12 I82A13 I82A19 I82A21 I82A22 I82A23 I82A29I82B11 I82B12 I82B13 I82B19 I82B21 I82B22 I82B23 I82B29 I82C11 I82C12 I82C13 I82C19 I82C21 I82C22 I82C23 I82C29 Z86718 Z8672

N181 N182 N183 N184 N185 N186 N189 R880 Z4901 Z4902 Z4931 Z4932 Z9115 Z940 Z992

H330 H331 H3320 H3330 H3340 H338 H3400 H3401 H3402 H3403 H341 H34210 H34811 H34821 H34831 H34831 H34832 H34833 H34839 H349 H350 H3510 H3511 H3512 H3513 H3514 H3515 H35161 H35171 H3520 H3521 H3522 H3523 H3530 H3531 H3532 H3534 H3535 H3536 H3537 H3538 H3540 H3541 H3542 H3543 H3545 H3546 H3550 H3551 H3552 H3553 H3554 H3560 H3561 H3562 
Table A-1. Continued

\begin{tabular}{|c|c|c|c|}
\hline CCC Codes & Conditions & Aggregated ICD-9-CM Codes & Aggregated ICD-10-CM Codes \\
\hline & & $\begin{array}{l}3623736240362413624236243 \\
3625036251362523625336254 \\
36255362563625736260 \\
36261 \\
36262362633626436265 \\
36266362703627136272 \\
36273362743627536276 \\
36277362813628236283 \\
3628436285362893629\end{array}$ & $\begin{array}{l}\text { H3563 H3570 H3571 Н3572 Н3573 } \\
\text { H3581 H3582 H3589 H359 H36 }\end{array}$ \\
\hline \multicolumn{4}{|c|}{ Nerve system disorder } \\
\hline 95 & $\begin{array}{l}\text { Other nervous } \\
\text { system disorders }\end{array}$ & $\begin{array}{l}3253321337203372133722 \\
337293410341134183419 \\
34461347347003470134710 \\
3471134803482348334830 \\
3483134839348434853488 \\
34893492349813498234989 \\
349935013502350835093510 \\
351135183519352035213522 \\
352335243525352635293530 \\
353135323533353435353536 \\
353835393540354135423543 \\
354435453548354935503551 \\
355235533554355535563557 \\
3557135579355835593560 \\
35613562356335643568 \\
356935703571357235733574 \\
357535763577357835781 \\
35782357893579358035800 \\
358013581358235883589 \\
359035913592359335943595 \\
3596359835981359893599 \\
781078117812781378177818 \\
7820784378457846078461 \\
78469792079307940079401 \\
794027940979410 \\
79411794127941379414 \\
794157941679417794197961 \\
\text { V124 V1240 V1241 V1242 } \\
\text { V1249 V415 V452 V484V485 } \\
\text { V493 V530V5301 V5302 } \\
\text { V5309 }\end{array}$ & $\begin{array}{l}\text { B2701 B2711 B2781 B2791 G08 G130 } \\
\text { G131 G132 G138 G210 G2111 G2119 } \\
\text { G212 G213 G214 G218 G219 G360 } \\
\text { G361 G368 G369 G370 G371 G372 } \\
\text { G373 G374 G375 G378 G379 G4720 } \\
\text { G4721 G4722 G4723 G4724 G4725 } \\
\text { G4726 G4727 G4729 G474 G4763 G500 } \\
\text { G501 G508 G509 G510 G511 G512 } \\
\text { G513 G514 G518 G519 G520 G521 } \\
\text { G522 G523 G527 G528 G529 G53 } \\
\text { G540 G541G542 G543 G544 G545 } \\
\text { G546 G547 G548 G549 G55 G560 } \\
\text { G561 G562 G563 G564 G568 G569 } \\
\text { G570 G571 G572 G573 G574 G575 } \\
\text { G576 G577 G578 G579 G580 G587 } \\
\text { G588 G589 G59 G600 G601 G602 } \\
\text { G603 G608 G609 G610 G611 G6181 } \\
\text { G6182 G6189 G619 G620 G622 G6281 } \\
\text { G6282 G6289 G629 G63 G64 G650 } \\
\text { G651 G652 G7000 G7001 G701 G70 } \\
\text { G7080 G7081 G7089 G709 G710 G711 } \\
\text { G712 G713 G718 G719 G720 G721 } \\
\text { G722 G723 G7241 G7249 G7281 G7289 } \\
\text { G729 } \\
\text { G731 G733 G737 G890 G8911 G8912 } \\
\text { G8918 G8921 G8922 G8928 G8929 } \\
\text { G893 } \\
\text { G894 G902 G9050 G9051 G90521 } \\
\text { G90522 G90523 G90529 G9059 G908 } \\
\text { G909' G910 G911 G912 G913 G914 } \\
\text { G918 G919 G92 G930 G932 G9340 } \\
\text { G9341 G9349 G935’ G936 G937 G9381 } \\
\text { G9382 G9389 G939 G94 G950 G9511 } \\
\text { G9519 G9520 G9529 G9581 G9589 } \\
\text { G959 G960 G9612 G9619 G968 G969 } \\
\text { G980 G988 G998 J1081 R200 R201 } \\
\text { R202 R203 R208 R209 R250 R251 R253 } \\
\text { R258 R259 R260 R261 R262 R2681 } \\
\text { R2689 R269 R270 R278 R279 R290 } \\
\text { R292 R414 R41840 R41841 R41842 } \\
\text { R41843 R41844 R4189 R430R431 R432 } \\
\text { R438 R439 R4701 R4702 R471 R4781 } \\
\text { R4782 R4789 R479 R481 R482 R488 } \\
\text { R489 R900 R9082 Z462 Z86011 Z8661 } \\
\text { Z8669 Z982 }\end{array}$ \\
\hline
\end{tabular}

Based on Clinical Classification Software-DIAGNOSES, January 1980 through September 2018. ICD, International Classification of Diseases. 
Appendix B. STUDY Variable Operationalization

Table A-1. Descriptions of Study Variables

\begin{tabular}{|c|c|c|c|c|}
\hline Domain & Variable & Type & Definition & Data Source \\
\hline \multirow[t]{2}{*}{ Teach-Back Experience } & $\begin{array}{l}\text { Medical } \\
\text { instruction }\end{array}$ & Binary & $\begin{array}{l}\text { Doctors or other health } \\
\text { providers gave } \\
\text { instructions that were } \\
\text { easy to understand }\end{array}$ & $\begin{array}{l}\text { MEPS-Household } \\
\text { Component: CAHPS }{ }^{\circledR}\end{array}$ \\
\hline & Teach-Back & Binary & $\begin{array}{l}\text { Doctors or other health } \\
\text { providers asked to } \\
\text { describe how to follow } \\
\text { the medical instruction } \\
\text { given. }\end{array}$ & $\begin{array}{l}\text { MEPS-Household } \\
\text { Component: CAHPS }{ }^{\circledR}\end{array}$ \\
\hline \multirow[t]{10}{*}{$\begin{array}{l}\text { Patient characteristics: } \\
\text { Socioeconomic }\end{array}$} & Age, years & Categorical & $\begin{array}{l}\text { Age when first entered } \\
\text { MEPS }\end{array}$ & $\begin{array}{l}\text { MEPS-Household } \\
\text { Component }\end{array}$ \\
\hline & Sex & Categorical & $\begin{array}{l}\text { Gender of respondents } \\
\text { during MEPS interview }\end{array}$ & $\begin{array}{l}\text { MEPS-Household } \\
\text { Component }\end{array}$ \\
\hline & Race/Ethnicity & Categorical & Race/ethnic background & $\begin{array}{l}\text { MEPS-Household } \\
\text { Component }\end{array}$ \\
\hline & Education & Categorical & $\begin{array}{l}\text { Highest degree of } \\
\text { education attained at } \\
\text { the time of interview }\end{array}$ & $\begin{array}{l}\text { MEPS-Household } \\
\text { Component }\end{array}$ \\
\hline & Family Income & Categorical & $\begin{array}{l}\text { Family income as a } \\
\text { percentage of poverty }\end{array}$ & $\begin{array}{l}\text { MEPS-Household } \\
\text { Component }\end{array}$ \\
\hline & Marital Status & $\begin{array}{l}\text { Binary (Yes } \\
\text { or No) }\end{array}$ & $\begin{array}{l}\text { Current marital status at } \\
\text { the time of interview }\end{array}$ & $\begin{array}{l}\text { MEPS-Household } \\
\text { Component }\end{array}$ \\
\hline & Employment & Binary & $\begin{array}{l}\text { Current employment } \\
\text { status at the time of } \\
\text { interview }\end{array}$ & $\begin{array}{l}\text { MEPS-Household } \\
\text { Component }\end{array}$ \\
\hline & $\begin{array}{l}\text { Immigration } \\
\text { Status }\end{array}$ & Binary & Foreign born status & $\begin{array}{l}\text { MEPS-Household } \\
\text { Component }\end{array}$ \\
\hline & Census Region & Categorical & & $\begin{array}{l}\text { MEPS-Household } \\
\text { Component }\end{array}$ \\
\hline & $\begin{array}{l}\text { Health } \\
\text { Insurance }\end{array}$ & Categorical & $\begin{array}{l}\text { Health insurance coverage } \\
\text { and types during the } \\
\text { study period }\end{array}$ & $\begin{array}{l}\text { MEPS-Household } \\
\text { Component }\end{array}$ \\
\hline \multirow[t]{2}{*}{$\begin{array}{l}\text { Patient characteristics: } \\
\text { Communication }\end{array}$} & $\begin{array}{l}\text { Perceived } \\
\text { English } \\
\text { Proficiency }\end{array}$ & Binary & $\begin{array}{l}\text { How well respondents } \\
\text { could speak English or } \\
\text { how do they feel when } \\
\text { conversing in English }\end{array}$ & $\begin{array}{l}\text { MEPS-Household } \\
\text { Component }\end{array}$ \\
\hline & $\begin{array}{l}\text { Hearing } \\
\text { Problem }\end{array}$ & Binary & $\begin{array}{l}\text { Indication of whether a } \\
\text { respondent had serious } \\
\text { difficulty hearing }\end{array}$ & $\begin{array}{l}\text { MEPS-Household } \\
\text { Component }\end{array}$ \\
\hline \multirow{5}{*}{$\begin{array}{l}\text { Patient characteristics: } \\
\text { Clinical/health-related } \\
\text { characteristics }\end{array}$} & $\begin{array}{l}\text { General Health } \\
\text { Status }\end{array}$ & Categorical & Perceived health status & $\begin{array}{l}\text { MEPS-Household } \\
\text { Component }\end{array}$ \\
\hline & $\begin{array}{l}\text { Current } \\
\text { Smoking }\end{array}$ & Binary & $\begin{array}{l}\text { Self-reported current } \\
\text { smoking status }\end{array}$ & $\begin{array}{l}\text { MEPS-Household } \\
\text { Component }\end{array}$ \\
\hline & Obesity & Binary & $\begin{array}{l}\text { Self-reported body mass } \\
\text { index }>29.9 \mathrm{~kg} / \mathrm{m}^{2}\end{array}$ & $\begin{array}{l}\text { MEPS-Household } \\
\text { Component }\end{array}$ \\
\hline & Hypertension & Binary & $\begin{array}{l}\text { Indication of a respondent } \\
\text { received a diagnosis or } \\
\text { was ever told that } \\
\text { having high blood } \\
\text { pressure by healthcare } \\
\text { provider }\end{array}$ & $\begin{array}{l}\text { MEPS-Household } \\
\text { Component }\end{array}$ \\
\hline & Hyperlipidemia & Binary & $\begin{array}{l}\text { Indication of a respondent } \\
\text { received a diagnosis or } \\
\text { was ever told that }\end{array}$ & $\begin{array}{l}\text { MEPS-Household } \\
\text { Component }\end{array}$ \\
\hline
\end{tabular}

Continued 


\begin{tabular}{|c|c|c|c|c|}
\hline Domain & Variable & Type & Definition & Data Source \\
\hline & & & $\begin{array}{l}\text { having high cholesterol } \\
\text { by healthcare provider }\end{array}$ & \\
\hline & Asthma & Binary & $\begin{array}{l}\text { Indication of a respondent } \\
\text { received a diagnosis or } \\
\text { was ever told that } \\
\text { having high cholesterol } \\
\text { by healthcare provider }\end{array}$ & $\begin{array}{l}\text { MEPS-Household } \\
\text { Component }\end{array}$ \\
\hline & $\begin{array}{l}\text { Chronic } \\
\text { obstructive } \\
\text { pulmonary } \\
\text { disease }\end{array}$ & Binary & $\begin{array}{l}\text { Indication of a respondent } \\
\text { received a diagnosis or } \\
\text { was ever told that } \\
\text { having COPD by } \\
\text { healthcare provider }\end{array}$ & $\begin{array}{l}\text { MEPS-Household } \\
\text { Component }\end{array}$ \\
\hline & $\begin{array}{l}\text { Diabetes Care: } \\
\text { Lifestyle } \\
\text { modification }\end{array}$ & Binary & $\begin{array}{l}\text { Respondents were asked } \\
\text { whether they were } \\
\text { being treated with diet }\end{array}$ & $\begin{array}{l}\text { MEPS-Diabetes Care } \\
\text { Survey }\end{array}$ \\
\hline & $\begin{array}{l}\text { Diabetes Care: } \\
\text { Oral } \\
\text { medication }\end{array}$ & Binary & $\begin{array}{l}\text { Respondents were asked } \\
\text { whether they were } \\
\text { being treated with oral } \\
\text { medications }\end{array}$ & $\begin{array}{l}\text { MEPS-Diabetes Care } \\
\text { Survey }\end{array}$ \\
\hline & $\begin{array}{l}\text { Diabetes Care: } \\
\text { Insulin } \\
\text { injections }\end{array}$ & Binary & $\begin{array}{l}\text { Respondents were asked } \\
\text { whether they were } \\
\text { being treated with } \\
\text { insulin }\end{array}$ & $\begin{array}{l}\text { MEPS-Diabetes Care } \\
\text { Survey }\end{array}$ \\
\hline \multirow[t]{3}{*}{ Diabetic Complications } & CVDs & Binary & $\begin{array}{l}\text { Self-reported diagnosis of } \\
\text { any CVD or identified } \\
\text { conditions using ICD-9 } \\
\text { or } 10 \text { codes }\end{array}$ & $\begin{array}{l}\text { MEPS-Household } \\
\text { Component \& Medical } \\
\text { Conditions Files }\end{array}$ \\
\hline & Kidney problem & Binary & $\begin{array}{l}\text { Self-reported kidney } \\
\text { problem associated with } \\
\text { diabetes or identified } \\
\text { conditions using ICD-9 } \\
\text { or } 10 \text { codes }\end{array}$ & $\begin{array}{l}\text { MEPS-Diabetes Care } \\
\text { Survey \& Medical } \\
\text { Conditions Files }\end{array}$ \\
\hline & Eye problem & Binary & $\begin{array}{l}\text { Self-reported eye problem } \\
\text { associated with diabetes } \\
\text { or identified conditions } \\
\text { using ICD-9 or } 10 \\
\text { codes }\end{array}$ & $\begin{array}{l}\text { MEPS-Diabetes Care } \\
\text { Survey \& Medical } \\
\text { Conditions Files }\end{array}$ \\
\hline \multirow[t]{3}{*}{ Hospitalization } & All-cause & Binary & $\begin{array}{l}\text { Any self-reported } \\
\text { hospitalization history } \\
\text { or identified hospital } \\
\text { admission records }\end{array}$ & $\begin{array}{l}\text { MEPS-Household } \\
\text { Component \& Hospital } \\
\text { Inpatient Stays Files }\end{array}$ \\
\hline & $\begin{array}{r}\text { Diabetes- } \\
\text { specific }\end{array}$ & Binary & $\begin{array}{l}\text { Identified hospital records } \\
\text { linked to diabetes using } \\
\text { ICD-9 or } 10 \text { codes }\end{array}$ & $\begin{array}{l}\text { MEPS-Medical Conditions } \\
\text { \& Hospital Inpatient Stays } \\
\text { Files }\end{array}$ \\
\hline & $\begin{array}{l}\text { Complication- } \\
\text { related }\end{array}$ & Binary & $\begin{array}{l}\text { Identified hospital records } \\
\text { linked to diabetic } \\
\text { complications using } \\
\text { ICD-9 or } 10 \text { codes }\end{array}$ & $\begin{array}{l}\text { MEPS-Medical Conditions } \\
\text { \& Hospital Inpatient Stays } \\
\text { Files }\end{array}$ \\
\hline
\end{tabular}

ICD, International Classification of Diseases; MEPS, Longitudinal Medical Expenditure Panel Survey. 